\title{
Caring Narratives in the Face of Perilous Situations: Voices of Karen Women in Communities in Thai-Burmese Border Zones
}

\section{Paiboon Hengsuwan}

Department of Women's Studies, Faculty of Social Sciences, Chiang Mai University, Chiang Mai 50200, Thailand

Corresponding author. E-mail: paiboon1988@yahoo.com

https://doi.org/10.12982.CMUJASR.2017.0010

\section{ABSTRACT}

The current situation in the Thai-Burmese borderlands can be labeled 'frontier capitalism', that is, capitalist expansion into the borderlands that is characterized by political conflict, state recognition that ethnicity issue playings a key role in preventing women and men from obtaining Thai citizenship, and competition for control of natural resources through development programmes. Among the numerous stakeholders involved are local Karen people, including women, who are asserting their rights over natural resources and protecting their livelihoods. This article argues that the women's motives are based on the ethics of care. Considering the precarious situations and the risks to sustainability of natural resources, Karen women at border villages have raised their voices to protect the future of their families and the community. However, their association with community men for joint action is riddled with many challenges. Therefore, they have to seek survival strategies and create opportunities to negotiate with frontier capitalism to secure better livelihoods.

KEYWORDS: Caring gender, Resource streuggles, Karen women, Thai-Burmes border zones. 


\section{INTRODUCTION}

Within Thai-Burmese border zones ${ }^{1}$, great political conflict and competition for natural resources exists among numerous stakeholders, including local and ethnic people in border villages, ethnic minority armed groups in border zones, Thai and Burmese soldiers, business persons and transnational corporations' employees. Although the Thai and Burmese states have attempted to control the Salween borderlands by using force and military mechanisms, capitalists intend to make profit by producing neo-liberal projects - Salween hydropower dam and water diversion projects (EarthRights International, 2005; TERRA, 2005). However, local Karen people, including women, who will be affected by these projects, have long struggled against them in order to maintain livelihood security and protect natural resources and the environment. Nevertheless, while engaging with state-led development programmes, women face difficulties embedded in gender norms.

\section{The Salween frontier of capitalism}

Frontier capitalization ${ }^{2}$ is the process of capital accumulation through natural resource transformation into commodities, known as commodification of nature (Polanyi, 1980; Smith, 1984; O'Connor, 1998). The Salween's resources have been commodified as Salween frontier capitalization $^{3}$ by transnational dam investors who have turned the Salween River into a hydro-electric production enterprise for

\footnotetext{
${ }^{1}$ The Salween River originates from the melting of ice at 4,000 MSL (Mean Sea Level), high on the Tibetan Plateau in the Himalayas. It flows down south through the mountains of Yunnan province in China and passes through Shan State and Karenni State in eastern Burma at 300 MSL. It forms the international border between Burma (Karen State) and Thailand (Mae Hong Son Province) for about 118 kilometers.

${ }^{2}$ According to Anna Tsing, a 'resource frontier' is a deregulated landscape that confuses the boundaries of law and theft, governance and violence, use and destruction (Tsing, 2005: 27-33). This peculiar form of capitalism is a complex construction (Laungaramsri, 2012: 466) which is not a naturally pre-existing phenomenon. It is derived from re-reading the frontier landscape, by the dominants, in order to legitimize order so as to manage and control local resources.

${ }^{3}$ Frontier capitalization has made a big change to the Salween borderlands since the $19^{\text {th }}$ century when the British forces first came to take control of Burma and annexed Burma's lands and border regions by military force. Later, during World War II, Japanese forces came claiming rights over lands and resources. By virtue of their superior coercive power, they extracted natural resources. Capital during this period was affiliated with the powerful regimes that ruled over Burma by military force (Grandstaff, 1976; Keyes, 1979; 1994; Renard, 1980; Winichakul, 1994; Bryant, 1997; Jorgensen, 1997; Marshall, 1997; Webster, 1998; Fink, 2001; Tangseefa, 2003;).
} 
trade in the regional energy market (Hengsuwan, 2012) and water supply through the Salween River diversion projects - the Lower Yuam Dam-Bhumipol Dam reservoir (TERRA, 2005). In addition, Salween frontier capitalization has worked in the Salween borderlands where state power is unclear. One has to agree with Pinkaew's proposition (2012) that the lower Salween river basin (Babel \& Wahid, 2009) did become a resource frontier that facilitated capitalization because the river, as a natural resource, was transformed into a commodity (electricity) that was sold in the energy market. In this process both the state, in association with capitalists (i.e., investors), and local people are competing for access to resources.

The current situation is a collusion among market players, particularly Transnational Corporations (TNCs) and states, to appropriate resources by introducing border development and forest management schemes. These phenomena are not different from the earlier teak timber industry in colonial and postcolonial Burma (Winichakul, 1994; Bryant, 1997). Similarly, the proposed Salween dam and water diversion projects operate within the idea of generating capitalisation in the Thai-Burmese border zones. These projects are parts of the neo-liberal process embedded in state practices (Polanyi, 1980), while a wider ethnic politics of these areas regarding environmental good governance has not yet emerged.

\section{Women's caring as survival strategy}

This study focuses on the understanding of responsibility among Karen women at the Thai-Burmese border zones as 'activities of care' (Gilligan, 1982), the ways in which they covertly and individually resist the gender inequalities they face at home and in the community $^{4}$ (Agarwal 1994; 1997; 2015). Karen women are expected to be housekeepers as well as to perform production activities as their roles and responsibilities, while the relation between production and reproduction varies over time and in space (McDowell, 1983; Devika, 2006). The woman-housewife-mother's role can be seen as that of practicing morality, that is, the ethics of care (Gilligan, 1982). These women care for the future as they are involved in earning money for their families, while demonstrating resourcefulness, self-sacrifice, and fiscal prudence that display altruistic qualities (Devika, 2006; Botti, 2015). Third world feminists, such as Gayatri Chakravorty Spivak and Chandra Thalpade Mohanty, have criticised the binary

${ }^{4}$ Women often lack the ability to overcome the material constraints they face, and move from individual to group articulation of their interests (Agrawal, 2015) 
opposition and essentialism of several modernists: coloniser/colonised, domination/resistance, modern/traditional, and culture/nature. Hence, they have tried to move beyond this dichotomy. As third space is an initial site of contestation and negotiation, Spivak suggests that third world women are not homogenous and cannot be essentialised or stereotyped as victims of patriarchal regimes even though as subaltern they are the 'underside of power' statically (Rofel, 1999) or cannot 'speak' (Spivak, 2010). They are political subjects with agency who have tried to contest or negotiate their positions in order to raise their voices ${ }^{5}$. Therefore, women's survival strategies are based on what they have experienced, and their efforts to have society understand their life and accept their identity as humans (Mohanty, 2003). Following this analysis, the study will examine the Karen women's ethics of care as strategies of survival expressed by their attempting to engage in and negotiate with development projects introduced by state and capitalists, as well as Karen men in household and community. The main question is how women have performed and negotiated through resource struggles and power relations involving suffering, the environment, and economic development which have resulted in perilous situations.

\section{METHODOLOGY}

This study was carried out over the period 2007-2010 and 2016. Semi-structured and in-depth interviews, and participatory observations were qualitative methods to gather primary information during fieldwork. In-depth interviews took place in each selected village and interview timing was normally about one hour. Participatory observation took place while visiting the villages and participating in their daily activities. Moreover, literature review was a tool to gather secondary information. The information collected was synthesized through content analysis. Four research sites were chosen, including three border villages along the Salween River on the Thai side to which I gave the pseudonyms Saw Myin Dong, Bon Bea Luang, and Muang Mean, and another village located in Mae Ngo National Park which I named Te La Kroh. These selected villages are all facing similarly precarious situations. They are located in the proposed hydropower development areas, ethnic villagers face Thai state recognition of citizenship, and they are situated in the political

\footnotetext{
${ }^{5}$ Rofel (1999) noted that "I also recognise that those who identify with or participate in the discursive space constructed as subaltern do so through and not outside of relations of power. These people actively engage their subalternity by changing and reinterpreting... the vision of modernity."
} 
conflict between the Burmese government and ethnic states. In terms of their livelihoods, their main income is from agriculture, selling agricultural products such as chili and vegetables. The success of farming depends on ecological and environmental conditions. The first field survey, plus a visit to a temporary shelter nearby the Salween River on the Burmese side was made between 9 and 11 May 2007. Subsequent fieldwork trips were conducted during 11-14 July 2007, 15-19 July 2008, 7-9 January 2009, 7-11 July 2009, 12-21 February 2010, 19-21 May 2016, and 12-14 July 2016. This study interviewed 31 key informants including 10 females (9 Karen; 1 Shan) and 21 males (18 Karen; 2 Muslim; 1 Shan). Key informants, particularly the females chosen, are engaged in the development activities of their communities. Some of them are ethnic leaders and representatives.

\section{RESULTS}

\section{Border villages in the precarious situations}

These border villages ${ }^{6}$ are far from the city. Centuries ago ancestors of the residents came from various areas in Tibet, travelling south on the Irrawaddy River. Some of them travelled down to the Salween and to the Mae Chaem River, in Chiang Mai province and settled down in the mountainous areas.

Most of the people in Saw Min Dong ${ }^{7}$ are of Karen ethnicity and some of them came from the Burmese side. Basically, they are farmers, growing rice, doing shifting cultivation, planting crops, fishing, and raising animals. To earn money, some of them are laborers, boat drivers, shop owners, local government staff. They also gather food and products from the forest and rivers. Bon Bea Luang village ${ }^{8}$ is a meeting point where many people come to do business, find jobs, visit relatives, and so on. Villagers are comprised of Christian Karen,

${ }^{6}$ Ai Chamnan (pseudonym), a local Karen of Saw Min Dong said: "If we have no good land for agriculture, then we will settle in another place. So we move a lot, finding good places for farming and fishing. Originally, we did swidden, like field rotating farming, moving from place to place, and later on we settled down, doing rice farming in the lowland. One important thing to understand about our culture is that we don't like any fighting. We don't like any conflict with other groups and having no peace. So we don't want to compete with other ethnic groups. We usually live very far away in the forest. We don't have any conflict with other groups. We live peacefully by ourselves. That is the way we prefer to live". (Interview, 13 July 2016). ${ }^{7}$ In 2013, the population was 743 (men 398, and women 345). In 2017, it was 926 (men 486, and women 440).

${ }^{8}$ In 2013, the population was 1,455 (men 772, and women 683). In 2017, it was 1,542 (men 864, and women 678). 
Muslim Burmese, and Buddhist Tai. Several government offices are located in this village - Border Patrol Soldier Unit, National Park Center, local government or Sub-District Administrative Organization Office. Muang Mean village ${ }^{9}$ is located downstream at the end of the Thai territory where the Salween River turns and flows into Burmese land, where the Hutgyi dam is planned to be built inside Burma. The precarious situations that villagers encounter are numerous. First, they are not recognized as Thai citizens by the state. Second, according to forest conservation policy, the Thai government has planned to expand more and more protected forest areas which affects their communities. Third, the proposed Salween hydropower dam projects are likely to generate many social and environmental impacts. Finally, the situations of political conflict and civil war in Burma that cause internal displaced people (IDP), forced relocation, and refugees have implications on Karen villagers in the Thai side as well.

To achieve state recognition, villagers have attempted to present themselves as subjects of the Thai state though connections to the monarchy. Villagers still recall that His Majesty King Bhumibol Adulyadej visited this area in 1983 and 1985. Pa Te Sae Yi (pseudonym), an elder of Muang Mean village, told me his memory of the village setting $^{10}$. In the long past the villagers used to live scattered out in isolation from others, then they gradually moved closer until they built a permanent village. The late King saw it was difficult for them and wanted to support them to do lowland rice farming. Thus the villagers think that the Thai state has to protect them as the state's subjects.

Thai citizenship is crucial for them to have access to government services, and mobility is a means to make their living and find jobs outside community (Pearson \& Kusakabe, 2013; Hengsuwan, 2017). However, Noh Luedee (pseudonym), a woman living in Muang Mean village, spoke to me of the problem of ID entitlement run by state, saying,

The government issues different colored ID cards, orange, yellow, red, etc. And one of them is for citizenship. So it is very difficult, so many categories, but theydon't give us the right to citizenship. (Interview, 13 July 2016).

\footnotetext{
${ }^{9}$ In 2017, the population in one hamlet was 884 (men 476, and women 408).

${ }^{10} \mathrm{~Pa}$ Te Sae Yi mentioned: "I don't remember the exact year, but when I was a young child, and my mother and father remembered that clearly. When the King visited us, it was still a very small village. It was only 5-7 houses. The only way of making a living at that time was to do rotational farming on the hill". (Observation, 13 July 2016).
} 
Similarly, students of the Centre for River Training (pseudonym) discussed this matter with a women's group in Muang Mean village. They explained that 20 per cent of the villagers do not have citizenship. Most villagers were born in Thailand, but the government did not give them citizenship mostly because their parents escaped from the war in Burma and were not able to obtain birth certificates for the children born in Thailand. Consequently, they are stateless.

Like other villages, these four villages are located in the forestlands thus facing foresters' threats (Bandittherdsakul, ed., 2013). Te La Kroh village is located in forestlands where the government will declare a new protected forest zone - Mae Ngao National Park ${ }^{11}$. To claim their rights, nevertheless, villagers joining up with local NGOs and foresters have been in negotiation on forest demarcation. Villagers state that their livelihood based on the rotational farming does not destroy the forest, but the state sees their way of living as threatening forest land. Therefore, the state's conservation policy causes conflicts between foresters and villagers over time.

On the dam issue, technocrats and energy developers argue that the Salween dams are needed to supply electric energy to generate economic growth and regional development. They also claim that villagers' lives will be improved. Therefore, hydro-electric dams have been proposed to be built on the Salween River. At the Thai-Burmese border, at least four dam projects are proposed: Tasang Dam or Muang Ton Dam, Weigyi Dam, Dagwin Dam, and Hutgyi Dam. These dams will create adverse impacts on the river ecosystem and on villagers (Akimoto, Ed., 2004). In addition, the situation became more serious when Prime Minister General Prayut Chan-ocha approved the Salween-Ping-Chao Phraya water diversion project (including the Mekong water diversion project) proposed by the Royal Irrigation Department in January 2016. The first proposed plan is to divert water from tributaries of the Salween River to the Bhumibol Dam to feed into the Central Plain ${ }^{12}$. Primarily, the lower Yuam River to Bhumibol Dam diversion route is the optimum choice, and will be completed within ten years (Achakulwisut, 2016).

\footnotetext{
${ }^{11}$ The Royal Forest Department has planned to establish this for more than 20 years.

${ }^{12}$ The Salween-Ping-Chao Phraya water diversion project was initially proposed in 1994. The project is expected to send about two billion cubic meters of water a year to Bhumibol Dam. It requires the construction of a dam, $202 \mathrm{~km}$-electricity lines, a water pumping station, and a $62 \mathrm{~km}$-water tunnel. It has raised concerns about the environmental and health effects on people who live in the dam site and along the proposed route of the tunnel (Achakulwisut, 2016).
} 
The Electricity Generation Authority of Thailand - the state-owned enterprise known as EGAT - has attempted to persuade villagers to accept the dam construction projects through exercising a philanthropic strategy (Shining, 2011). For example, EGAT staff came to talk with residents of Saw Myin Dong village in 2008. They said that the government is going to build the Hutgyi Dam and take responsibility for affected residents by arranging land, paying compensation, and training them for new jobs. But the villagers did not accept these proposals because of the concern about their future livelihood security. They prefer to live in their own place. Saw Myin Dong resident Moh Yupin (pseudonym) raised the issue, saying, "We can move our house, but how can we move our rice fields? How can we live without farmlands?" (Hengsuwan, 2012).

In addition, EGAT strategically supported the 2010 stateless children's day festival organized by a local NGO, namely Community Development Centre (pseudonym). It took place at the Centre's compound and many NGOs supported this activity, as did government agencies, including the Border Patrol Soldier Unit and EGAT.

The last precarious situation is political conflict between Burmese government and ethnic states in Burma, which has created internal displaced people (IDP), forced relocation, and refugees for decades (Grundy-Warr, 2001; 2004; Thailand Burma Border Consortium, 2006; 2012; The Border Consortium, 2012; 2017). Many people were forced to evacuate from home by Burmese military intrusion. For example, in 2007, I visited the Ee Tu Hta IDP camp ${ }^{13}$ located near the tributary of the Salween River where victims of conflict have been fleeing their villages. They were compelled to live/hide in the jungle or take shelter in refugee camps along the Thai-Burmese border, or migrate to Thailand, to be classified by the Thai government as 'stateless people' (Tangseefa, 2003; Grundy-Warr, 2004; Spindler, 2015; The Border Consortium, 2017).

\footnotetext{
${ }^{13}$ In 2016, the number of IDP in this camp is 3,136 and the number of total IDP population is 8,816 , while the number of total refugee population is 102,607 (The Border Consortium, 2017).
} 
Villagers on the Thai side also felt sympathy for them ${ }^{14}$. Moreover, villagers themselves also experienced impacts from the war when the military opened fire across the border. Pa Te Sae Yi said,

It was very sad. Because of the war on the Burma side, a huge bomb came across the river... It entirely destroyed the school 30 years ago. When the war in Burma was very bad, we were so scared. We had to run into the forest and into a safer neighbouring village. We stayed until it became peaceful and then came back home. We rebuilt the whole school again, even bigger than before. And then in 1992 another bomb came from the Burma side destroying the school again. (Observation, 13 July 2016).

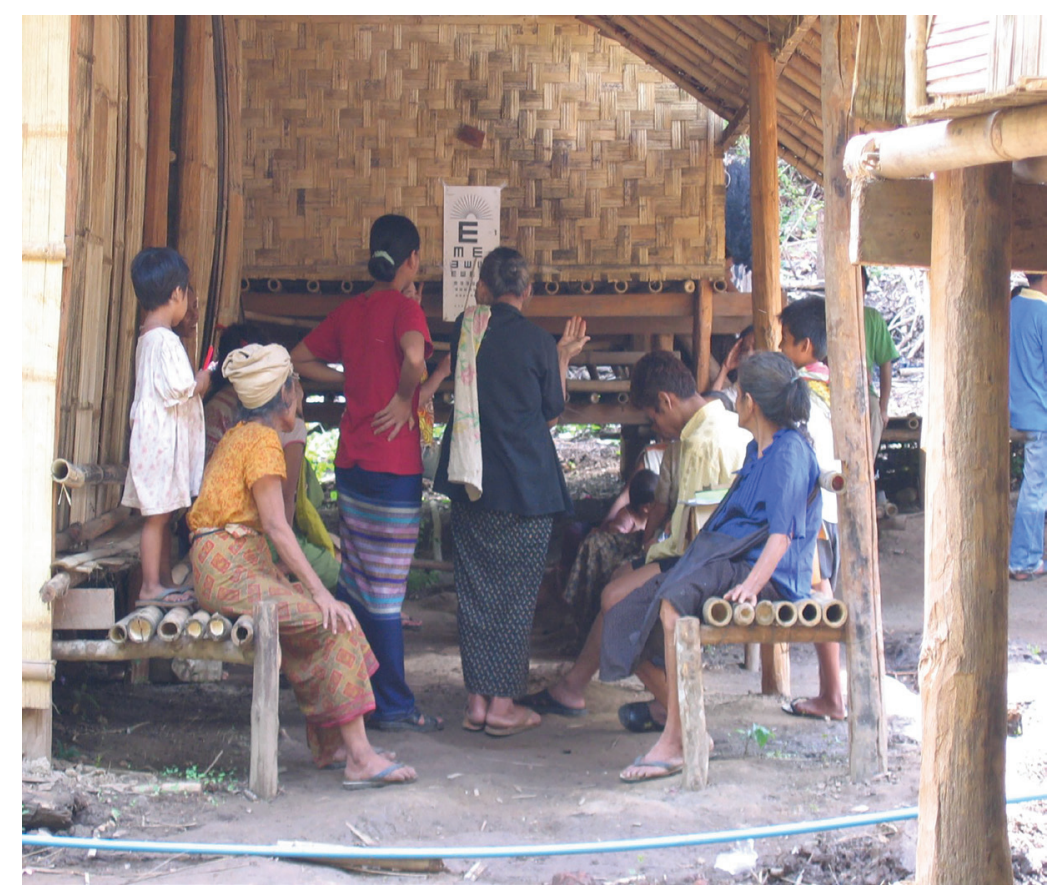

Figure 1. IDP in the Ee Tu Hta camp inside Burma.

\footnotetext{
${ }^{14} \mathrm{~Pa}$ Te Sae Yi reflected: Of course, we are brothers and sisters, so we will take care of them. It is not easy for them to be refugees. You can imagine that many people live very closely with very few resources. Let's say refugees have to look for mushrooms to eat in the forest, but the amount is inadequate for everybody. And diseases, life is very poor, when you live densely in the refugee camp, disease spreads very easily and also public health problems (Observation, 13 July 2016).
} 
Concerning border security, both local Thai and Burmese government agencies formally attempt to build relationships across borders, trying to quell disturbances that cause outbreaks of disorder at the border area. They try to present this border-zone as safe for all and potentially another destination for tourists to visit. In 2010, the Provincial Administrative Organization and the Provincial Tourism and Sport Office ran the $2^{\text {nd }}$ Thai-Burmese boat racing festival at Bon Bea Luang. They aimed to organize it as an annual festival and the provincial governor came to chair the open ceremony and high-ranking persons of the Burmese military were invited to participate in the festival. There were many activities taking place during the day and at night time, such as beach volleyball competition, boat racing, a Miss Salween contest and music. Unfortunately, the following year, 2011, the festival was suspended due to conflict between Thai and Burmese soldiers who got into a fight with each other while drinking alcohol. The next day a Thai soldier who was ethnic Karen was found shot dead. The situation sometimes gets out of control.

Villagers have generally experienced on a daily basis these problems of state unrecognition, the proposed hydropower development, and political conflict along the Thai-Burmese border. However, Karen women, whose roles and responsibilities are expected to be mother or housewife experience more pressure and impact as burdens are put on their shoulders when farming productions are disturbed. Some areas that used to be farmland are off-limits for farming by the state conservation policy, and hydropower development will inundate the low-lying village areas and streams. As the domestic economy becomes unpredictable, the insecurities of life might lead to poverty in the end.

\section{Asserting local rights to livelihoods}

In general, we understand that people assert their rights to protect their livelihoods and environment with reference to the principles and ideology of universal human rights. However, I found that the ethnic Karen in the Salween borderlands are trying to use community rights as a tool to protect their livelihoods and environment, along with human rights recognized by the 1997 Thailand constitution and later the 2007 Thailand constitution. Therefore, they have called for protection of the natural resources across the Salween River and their reason is based on the principle of community rights.

Considering the precarious situation and the risks to sustainability of natural resources, local people in the border areas have raised their voices to protect their families and their communities future. Among all walks of life, there are women (and men) of Karen ethnicity, who assert 
their rights over the natural resources across the Salween River. However, the previous constitution was disrupted by the 2010 military coup d'état that overthrew human and community rights. The concept of community rights was not fully applied in the new 2017 Thailand constitution. Therefore, the ethnic Karen people can no longer refer to or make claim of community rights, as de jure, to protect their livelihoods and environment.

The community rights movement has been mobilized nationwide (Trakarnsuphakorn, 2008) by many local communities, in association with scholars, NGOs and journalists over three decades. But the movement cannot go further in terms of state and policy advocacy due to unstable political situations. The movements got exhausted and the community forest draft was not approved by the state. Therefore, they changed their movement strategy, turning from movement and protest at national level to their own community at local level. By shifting contesting terrain from national scale to local level, most of their activities are about everyday forms of resistance (Scott, 1985) such as negotiation with authorities rather than direct movement and resistance to state power (Sae Chua, 2014).

In mid-May 2016, the Community Development Centre organized a meeting at $\mathrm{Te} \mathrm{La}$ Kroh village. There were about 25 people, both men and women, who came from neighboring villages, which are members of local sub-watershed network, to participate in the meeting. Men and women sat down to form a big circle in a house of the sub-watershed network leader. During discussion, I realized that the group of men has likely retreated from their work within and beyond their village because the front line of the working team is the old generation who has run the network for decades. Meanwhile, the new generation to continue their duties has not emerged strongly. $\mathrm{Pa}$ Te Lerd (pseudonym), an elderly leader, expressed his main concern, desperately saying,

I have continually worked and been in a leadership position for many years. Many of my friends have gotten older and so they are not able to continue working. They already quit their work in the network. On the other hand, the younger generation persons are very few. Should the network be abolished or not? What do you guys think? (Observation, 19 May 2016).

By contrast, the women's group is energized by their numerous benefit-raising activities for families. They have enthusiasm for social life of the community. While being engaged with people-state-market negotiations, the Karen women actively took it upon themselves to achieve higher incomes. But many of them still did not get full Thai citizenship, meaning that their mobility continues to be constrained. 
However, their association with community men for joint action is not smooth or easy; it is in fact riddled with many challenges. Noh Somsri (pseudonym), a member of the women's group, raised her issues in the meeting, saying,

The problem is that those who went to join trainings went back with no rice to eat. How are we going to survive? Also meetings often took place outside our communities where women couldn't participate, even though we would like to. Women are worried about who's gonna take care of home, raise kids, feed pigs, and the other concerns if we go out to the meeting venue. (Observation, 19 May 2016).

Furthermore, women still need men's help in terms of emotional support. Noh Somsri reflected on her loneliness, saying,

Women really lack knowledge. We cannot read, so how can we go to Chiang Mai, or Bangkok to attend meetings. We don't really know how to get the right bus. We must have someone to go with us. Having, at least, a man to lead us will be fine. (Observation, 19 May 2016).

In some cases, the Karen women not only feel lonely, but also are oppressed by men. Some women are able to go out, traveling to attend meetings or field trips organized by NGOs and networks. Nevertheless, traveling out of the village with a man or having a meeting with other men tends to be seen as immoral according to strong traditional beliefs.

In brief, Karen villagers in the communities along the Thai-Burmese border still have a traditional way of life of sharing cross-border livelihood resources and culture with others. However, their daily life is precarious. First, the Thai and Burmese governments try to keep the borderlands free of people's unrest and resistance against the government, fearing that these may turn into conflict between the state and people. However, disputes and conflicts between ethnic people, state agencies of both sides still happen. Second, the Karen ethnic people in the Salween borderlands can no longer claim community rights to protect their livelihoods and environment due to the 2010 military coup d'état that interrupted the community rights act. The government centrally consolidated power to control forestland that, in turn, separated villagers from their resources when they lost their power to control and manage them.

At the community level, the ethnic Karen women co-work with the men in their community to make a living and protect their rights and environment, as well as trying to work with local NGO activists 
in order to receive entitlement to citizenship in the negotiation with state agencies. In their view, having full Thai citizenship is a means to get access to state services and the labor market. In fact, daily mobility is a kind of women's survival strategy, but the government has taken greater control over their movement for security and development reasons (Pearson \& Kusakabe, 2013; Kusakabe \& Vongphakdy, 2014). In reality, they still keep traveling beyond their village space, even without getting permission from the authorities.

Moreover, ethnic Karen women have faced difficulties making their livelihoods secure during struggles against the state's forest conservation scheme and the dam investors. Working with men in communities to motivate environmental and political actions can be awkward to maneuver. Women's intention of community participation is opened to conjecture about being unfaithful, having been caught in mobility, and expressing emotional needs.

\section{Karen women's voices: Two case studies}

The life and activities of two ethnic Karen in their communities were selected to narrate with respect to caring for their future and their survival strategy as a way of resistance to state-led development and negotiating with their male partners under the precarious situation in which they live.

Moh Yupin: "We are the eggs, and government is stone". Moh Yupin, 67 years old, has been living in Saw Min Dong village. I first met her in 2009, and she told me about her life and the borderlands situation almost 60 years ago. Her father was with the first group of Karen families to settle down together as a village and she is the second generation. Her father was education-minded and wished to raise his children to become models of educated Karen. During that time when she was young, it was possible to travel quite freely across the border until the military battles took place. She said,

At that time I was 10 years old and I was very small. My father sent me to school. I considered going to high school at Noh Yu Tha in Burma because my English was so good. But a teacher said that I was too young to go there, that it was too far. So I studied at a closer place along with three friends who were older than I. We studied mathematics, English, Burmese and Shan languages, but not Thai. We stopped many times when Burmese (soldiers) invaded and confiscated Karen lands. The school was destroyed. Then I came back to stay in Thailand, and I didn't know what to do. I really wanted to study, but I couldn't. So I moved to live with my siblings in a 
village close to Mae Sariang town and I went to study informal education there. I also learned typing, which is not useful now. I totally forgot it. I thought that my studying was useless. And you can see that political and military conflicts have continued until now. (Interview, 8 July 2009).

It is very challenging for villagers to deal with the Salween hydro-power dam projects. They have run anti-project campaigns both locally and at the national level, as well as joining the anti-Salween dam networks. They (mostly males) have sometimes participated in international campaigns. However, Moh Yupin tends to perceive the dam projects in another way. As she put it,

I cannot be against the dam, but I myself disagree with dam construction. We are the eggs, and government is a stone. The eggs break when they hit the stone. When the stone hits the eggs, the eggs are broken. Hence, we will break down for sure if we confront the government. (Hengsuwan, 2012).

For her, compared to the government, she is so powerless that the only thing she can do to deal with dam projects is to pray to God for mercy. She said, "If the dam is built, it means God allows the dam builders to succeed. Nowadays, villagers keep praying to God in church, asking Him to stop the Salween dam projects". (Hengsuwan, 2012).

The underlying message of what she said is that the villagers belong to and are political subjects of the state, which should recognize them. Moh Yupin imagines that the Thai government should be a protector that would prevent any danger or harm from coming to their villages, rather than threatening villagers. However, she does not directly pressure the government. Instead she conducts caring activities at the community level. The women's group in Saw Min Dong is very active in running schooling for their children. She has worked to teach the young generation both religion and education for many years, saying,

I am very happy that our children are interested in education and religious beliefs for their life. We come to live together and practice religion every day. I tell the kids to study the Bible, and I teach them songs. (Interview, 14 February 2010). 
Generally, the government rarely provides education in very remote villages. Instruction in education and religion that Moh Yupin has done stems from her own personal intention to prolong her village's life and ethnicity. On the one hand, Moh Yupin's activities show that Karen women engage in socialization in the public sphere, where men accept their position. On the other hand, the community became a site of struggle as the meaning of home is constructed by active females. Moreover their male partners in the community donot resist this daily survivalstrategy. In doing so, the different voices raised by women should be heard and recognized.

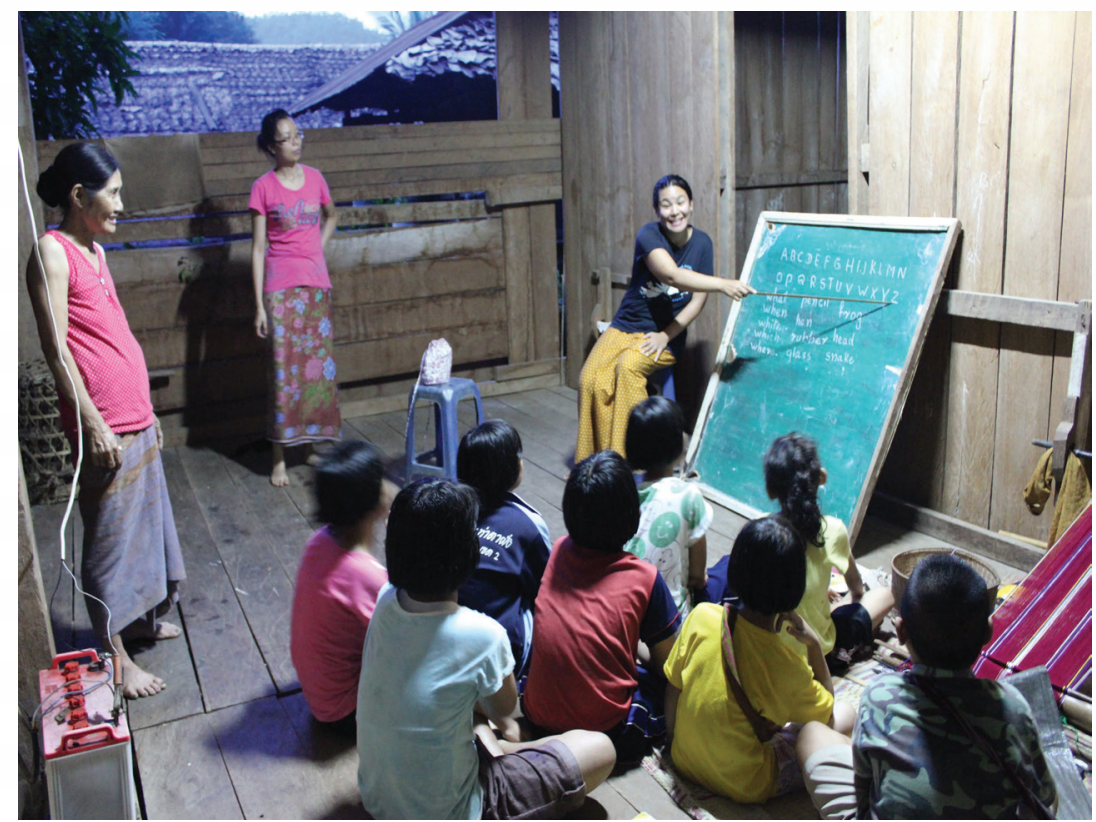

Figure 2. Moh Yupin joining children teaching class at night.

Noh Luedee: "We learn to improve ourselves". Noh Luedee, age 30, is an active woman leader of Muang Mean village. She and neighbouring women initially formed a group to run agricultural production and economic activities to increase their families' wealth in 2012.

The Community Development Centre has worked with villagers on certain issues - entitling citizenship; land, water, and forest issues; and women's and youth issues. Recently, it has been running women's groups in the villages. The project is supported by Kindernothilfe Organisation in Germany to help the women create micro-credit organizations, launch small businesses, and find solutions to their problems. They introduced the project to Karen females and some women volunteered to do the activities. 
In joining this program, women have the opportunity to strengthen their potential, and even increase their power to negotiate with the men in their family and at the community level. They realize that they gained economic and social benefits from it. I found that they are well organised. After receiving training, they set up a micro-credit group on 4 May 2015. Two groups of micro-credit organizations were formed. The first has 15 members, called Sho Ka Phor which means "bright women lead". The second has 11 members, and called Phor Mue Lae Ler Ya which means "women can lead". Noh Luedee told me their proud story,

Each member has to pay a daily fee of 10 baht. At the beginning, we felt there was no economic channel. We didn't know how to run a business. But within a year, we had saved about 20,000 baht. The activities that we have done include growing vegetables and selling them to the school in our community to make lunch for students. We also sold tea and coffee at a school sports day. We are now learning to improve ourselves to support our family and community. (Interview, 14 July 2016).

Basically, their lives are based on a subsistence economy and selling agricultural productions, fishing, and labor outside the village. Saving money and micro-credit groups' activities are another channel for them to increase their income. Therefore, micro-credit groups in the community can be seen as constructive spaces of 'women-for-themselves' (Agrawal, 2015). It is a mode of responsiveness to improve their family's quality of life and income. They also run business activities to accumulate money and share profits among the members. Significantly, their spirit and mind are growing, strong, and confident, in terms of knowing self, that they are visible subjects which are accepted by men in their family and community. For example, Noh Luedee's husband observed that women are important driving forces leading their community into the future.

Even though women's roles and movement are restricted by the double burdens of gender and ethnicity as "the other", Karen women try to overcome these burdens to make a living for the time being. Since NGOs have come to work with them, they have had more opportunities to learn and gain experience outside their community. Particularly, they have searched opportunities to acquire Thai citizenship recognized by the Thai state, which is very important for them to access basic government services and labour markets. They are constructing a meaning of home that will not be destroyed by hydropower development for the future generations. Moreover, they are forming small women's groups by incorporating their family activities into community economies and launching small businesses to empower women themselves. 


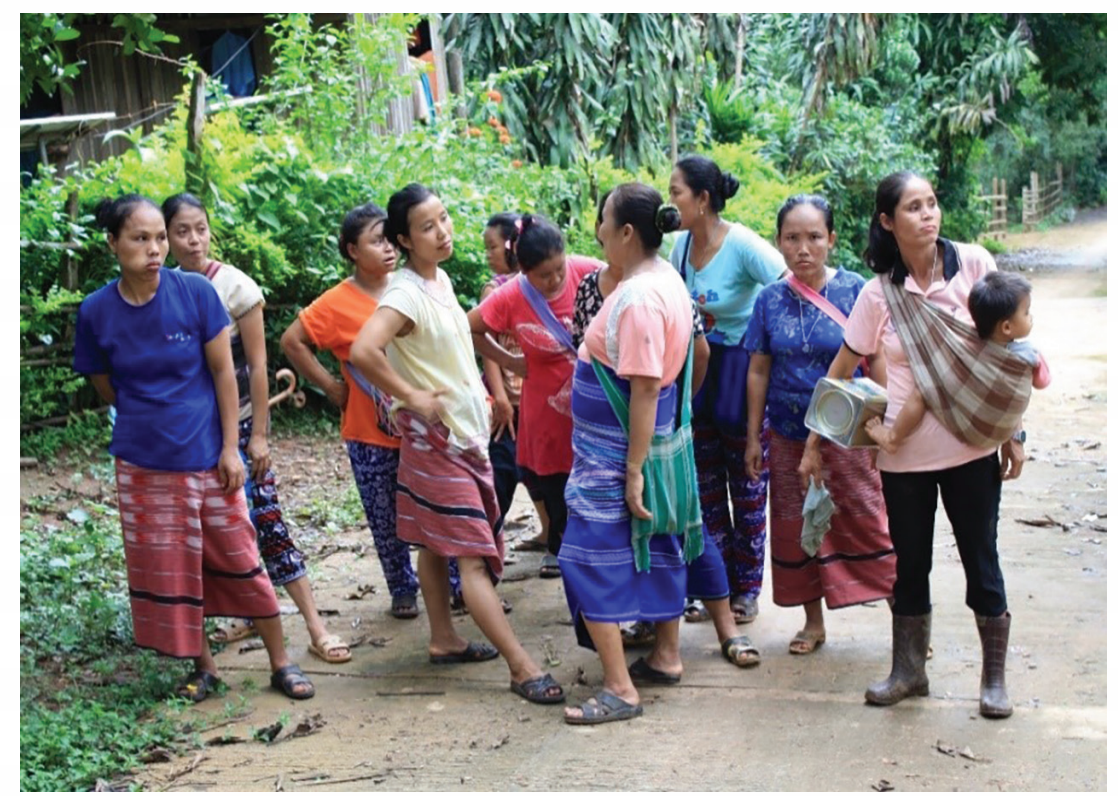

Figure 3. Noh Luedee and her friends in Muang Mean hosting.

\section{DISCUSSION}

The study focuses on how the women survive and respond to precarious situations and gender norm regulations which they experience on a daily basis. Women have used negotiating strategies, teaching education and religion, and organizing micro-credit groups, within the given precarious situation.

\section{Women's agency and strategies for survival}

Gender regimes direct the way in which gender roles are situated in a society through gender-special practices $^{15}$ (Connell, 1987; Counsell, 2016). Accordingly, Connell (1987) proposes that accomplishment of gender depends on the social context in which women and men have different behaviors that respond to different social expectations. Karen men perform masculine character and male roles as breadwinner and leader of the family. Karen women's roles include those of childcare, kinship,

\footnotetext{
${ }^{15}$ People display their gender, which is an idealized masculine or feminine notions. However, that they themselves are not natural, essential, or biological, but constructed in nature, reinforces notions of gender as an 'essential' characteristic (Hazelsapien, 2014).
} 
sex, recreation, provider and housekeeper. In this regard, doing gender is unavoidable (West \& Zimmerman, 1987).

Karen women have tried to overcome the double burden of gender and ethnicity, by negotiating their position with men in the community and the state. The data shows that Karen women's caring acts as survival strategies can turn against the hydropower development of the states and capitalists, whereas they act as agency within the limits of the gender norms that they cannot escape from (Mahmood, 2004). Women are raising their voices through caring narratives, thereby articulating a hegemonic state discourse of development and gender norms of Karen ethnicity. As political subjects, they are reflexive about what they have done intentionally and experienced internally, in relation to men. However, as a different voice (Gilligan, 1982), Karen women speak out with their caring ethics in terms of responsible care for relationships, binding interconnected vulnerable selves (Botti, 2015) with awareness and understanding of the situation taking place around them, which is not totally dominated by male bias. To some extent, we can conceptualize these women as exercising female agency (Danius, Jonsson \& Spivak, 1993) responsible for caring for others, not dominated by the patriarchal system, but negotiating with and resisting it (Mahmood, 2004).

Generally the "sexual division of labour" lies in the binary vision of the domestic and the public. However, we cannot absolutely separate women's roles and activities in everyday life (McDowell, 1983; Agarwal 1994; Massey, 1995; Devika, 2006; Botti, 2015). Karen women express most concretely at household and community levels rather than outside of community spaces. While they represent themselves as the weak who need state protection, they criticize the state for not taking care of them, which is a women's tool "everyday life resistance" (Scott, 1985). They seek choices in exercising decision making by their participation in groups and organizations. Working with their group encourages women to reclaim the power to build self-empowerment enabling them to achieve self-directed goals (Mahmood, 2004).

\section{Villagers' voices to resist the state-led development programmes}

Villagers view the Salween River as a woman and as a living, sacred river. Ai Kai (pseudonym), a villager of Muang Mean, said,

It flows from the sacred mountain in the shape of a woman's vagina. She has periods with blood coming out every month and flowing down. The Salween River becomes red in April every year. There are also seven underground streams from that mountain flowing into the Salween and those are sacred streams, one of which is very sacred and pure. If you drink water from it, you will be blessed. (Hengsuwan, 2012). 
To the Karen people, this perception of the Salween River reflects the co-existence of humans and nature in the way that they rely on nature and thus are obliged to protect nature. The developers, however, view the Salween solely as a natural resource with enormous reserves for generating hydro-electric power, or view the forest as commodity for exploitation to enable economic growth. These different perceptions have led to conflict and affected villagers' ability to control resource utilization (Vandergeest \& Peluso, 1995; Peluso \& Vandergeest, 2001).

Women's roles and responsibilities are not limited to the household level, but extend to the community as they have participated in and engaged with community rights and environmental protection campaigns. In the case of contested terrain of land and forest in Chiang Mai, Karen women are very active and have taken positions of resistance leaders (Trakarnsuphakorn, 2008). Likewise, Karen women living along the courses of the Salween River and tributaries have engaged in protecting community rights and environment in the Salween borderlands.

While Karen women have tried voicing their emotional suppression and loneliness, civil society has paid insufficient attention to their life and position in society. It is an intersectionality of ethnicity, unrecognized citizenship, male domination, and invisible subjects in hydropower development that indicates diversity and heterogeneity among women. It is time to fundamentally rethink relations between the environmental movement and women's issues since NGO activists have attempted to encourage local women to engage in community rights movements and anti-dam campaigns but without serious concern for their life experiences. For this reason, intersectionality should be deployed as women are diverse regarding daily survival activities and participation in development initiatives supported by NGOs.

\section{CONCLUSION}

From qualitative information and content analysis, several conclusions can be made. First, the villagers have been living under precarious situations imposed by the military's national security policies, political conflict in Burma creating IDP and refugees across the Thai-Burmese border, dam development by states and capitalists, forest conservation policies implemented by the Thai government, and economic pressure to earn a living.

Second, Karen women have created strategies to survive these situations. At the same time they have engaged equally with men in such actions as raising their voices about the Thai citizenship registration pro- 
cess, joining the anti-dam campaign, and trying to express themselves as subjects of state. Men and women also collaborate in creating mobility strategies, i.e. fleeing as IDPs and refugees and moving out of the community to get jobs in towns and cities. Importantly, women have created their own communal space in terms of development activities and youth education as well as empowering their own groups in running micro-credit enterprises.

However, at the same time, their survival strategies have certain limitations, as the process of citizenship entitlement is slow and complicated. Moreover, Karen women's engagement in campaigns outside the community still face oppression from men.

\section{REFERENCES}

Agarwal, B. (1994). Gender, resistance and land: Interlinked struggles over sesources and meanings in South Asia. The Journal of Peasant Studies, 22(1), 81-125. https:/ / doi.org/10.1080/030661594 08438567

Agarwal, B. (1997). 'Bargaining' and gender relations: Within and beyond the household. Feminist Economics, 3(1), 1-51. https:// doi.org/10.1080/13547097338799

Agarwal, B. (2015). The power of numbers in gender dynamics: Illustrations from community forestry groups. The Journal of Peasant Studies, 42(1),1-20.https:/ / doi.org/10.1080/03066150.2014.936007 Akimoto, Y. (Ed.). (2004). The Salween under threat: Damming the longest free river in southeast Asia. Chiang Mai: Salween Watch, Southeast Asia Rivers Network, Centre for Social Development Studies. Achakulwisut, A. (2016, January 18). Water diversion schemes no easy feat. Bangkok Post. Retrieved from https://www.pressreader.com/ thailand/bangkok-post/20160118/281732678488532

Babel, M.S., \& Wahid, M.S. (2009). Freshwater under threat South East Asia: Vulnerability assessment of freshwater resources to environmental change mekong river basin. Nairobi, Kenya: United Nations Environment Programme and AIT.

Bandittherdsakul, L., (Ed.). (2013). Mae Om Ki: Live of the forest and myths in justice process. In Thai. Bangkok: Human Rights Lawyers Association.

Botti, C. (2015). Feminine virtues or feminist virtues? The debate on care ethics revisited. Ethics and Politics, 17(2), 107-151. 
Bryant, R.L. (1997). The political ecology of forestry in Burma 1824-1994. London: Hurst \& Company.

Connell, R.W. (1987). Gender and power: Society, the person and sexual politics. Stanford: Stanford University Press.

Counsell, J.W. (2016). Identifying and analyzing causes of violence against women in Shan migrant communities according to NGO workers and Shan migrant in Chiang Mai. ASR: CMU Journal of Social Science and Humanities, 3(2), 101-113. https:// doi.org/10.12982/CMUJASR.2016.0006

Danius, S., Jonsson, S., \& Spivak, G.C. (1993). An interview with Gayatri Chakravorty Spivak. Boundary, 2(20), 24-50. Retrieved from http:/ / www.jstor.org/stable/303357

Devika, J. (2006). Negotiating women's social space: Public debates on gender in early modern Kerala, India. Inter-Asia Cultural Studies, 7(1), 43-61. htttps://doi.org/10.1080/14649370500463125

EarthRights International. (2005). Flooding the future: Hydropower and cultural survival in the Salween river basin. Retrieved from https: / / earthrights.org/blog/flooding-the-futurehydropower-and-cultural-survival-in-the-salween-river-basin/

Fink, C. (2001). Living silence: Burma under military rule. Bangkok: White Lotus.

Gilligan, C. (1982). In a different voice: Psychological theory and women's development. Cambridge, Massachusetts, and London: Harvard University Press.

Grandstaff, T.B. (1976). Swidden society in north Thailand: A diachronic perspective emphasizing resource relationships. (Doctoral Dissertation). University of Hawaii. United States.

Grundy-Warr, C. (2001). Regime security, contested sovereignty and the problem of long-term displacement along the Thai-Myanmar/ Burma Border. Singapore: National University of Singapore. Grundy-Warr, C. (2004). The silence and violence of forced migration: The Myanmar-Thailand border. In Ananta, A., \& Arifin, E.N. (Eds.). International Migration in Southeast Asia. (pp. 228-272). Singapore: Institute of Southeast Asian Studies, National University of Singapore.

Hazelsapien. (2014). Reviewing west and zimmerman - Doing gender. Retrieved from http://hazelsapien.blogspot.com/2014/03/ reviewing-west-zimmerman-doing-dender.html? $\mathrm{m}=1$ Hengsuwan, P. (2012). In-between lives: Negotiating bordered terrains of development and resource management along the Salween river. (Doctoral Dissertation). Chiang Mai University. Thailand. 
Hengsuwan, P. (2017). Living with threats and silent violence on the Salween borderlands: An interpretive and critical feminist perspective. Regional Journal of Southeast Asian Studies, 2(1), 69-121.

Irrawaddy Dolphin. (2016, January 15). Dusting off the project to divert Salween water to Chao Phraya Basin. In Thai. The Nation Weekly. Retrieved from http://transbordernews.in. th/home/ ?p=11347

Jorgensen, A.B. (1997). Foreword. In Marshall, H.I. The Karen people of Burma: A study in anthropology and ethnology. Bangkok: White Lotus Press.

Keyes, C.F. (1979). The Karen in Thai history and the history of the Karen in Thailand. In Keyes, C.F. (Ed.). Ethnic Adaptation and Identity: The Karen on the Thai Frontier with Burma. (pp. 25-61). Philadelphia, Pennsylvania: Institute for the Study of Human Issues.

Keyes, C.F. (1994). The Nation-state and the politics of indigenous minorities: Reflections on ethnic insurgency in Burma. A paper presented at a Conference on 'Tribal Minorities and the State', Organised by the Harry Frank Guggenheim Foundation in Istanbul.

Kusakabe, K., \& Vongphakdy, S. (2014). Gender vulnerabilities of resettlement and restricted mobility of ethnic groups in northern Laos. In Lund, R., Kusakabe, K., Panda, S.M., \& Wang, Y. (Eds.). Gender, Mobilities, and Livelihood Transformations: Comparative indigenous people in China, India, and Laos. (pp. 134165). London and New York: Routledge.

Laungaramsri, P. (2012). Frontier capitalism and the expansion of rubber plantations in southern Laos. Journal of Southeast Asian Studies, 43(3), 463-477. https://doi.org/10.1017/S0022463412000343

Mahmood, S. (2004). Politics of piety: The Islamic revival and the feminist subject. Princeton: Princeton University Press.

Marshall, H.I. (1997). The Karen people of Burma: A study in Anthropology and Ethnology. (Reprinted from the 1922 edition) Bangkok: White Lotus Press.

Massey, D. (1995). Spatial division of labour: Social structures and the geography of production. ( $2^{\text {nd }}$ ed.). London: Palgrave, Macmillan Press.

McDowell, L. (1983). Towards an understanding of the gender division of urban space. Environment and Planning D: Society and Space, 1, 59-72. 
Mohanty, C.T. (2003). Feminist without borders: Decolonizing theory, practicing solidarity. Durham: Duke University.

Morris, R.C. (2010). Introduction. In Rosalind C. Morris, (Ed.), Can the subaltern speak? Reflections on the history of an idea. (pp. 1-18). New York: Columbia University Press.

O'Connor, J. (1989). Natural causes: Essays in ecological Marxism. New York and London: The Guilford Press.

Pearson, R., \& Kusakabe, K. (2013). Thailand's hidden workforce: Burmese migrant women factory workers. Chiang Mai: Silkworm Books.

Peluso, N.L., \& Vandergeest, P. (2001). Genealogies of the political forest and customary rights in Indonesia, Malaysia, and Thailand. The Journal of Asian Studies, 60(3): 761-812.

Polanyi, K. (1980). The Great transformation. (The $2^{\text {nd }}$ printing). New York: Octagon Books.

Renard, R.D. (1980). Kariang: History of Karen-T'ai relations from the beginning to 1923. (Doctoral Dissertation). University of Hawaii. United States.

Rofel, L. (1999). Other modernities: Gendered yearning in China after socialism. Berkeley: University of California Press.

Sae Chua, B. (2014). Redefining citizenship rights: The community forest movement in Thailand and strategic rights claim. (Doctoral Dissertation). La Trobe University. Australia.

Scott, J.C. (1985) Weapons of the weak: Everyday forms of peasant resistance. New Haven, CT: Yale University Press.

Shining, N. (2011). Evaluating the implementation of EGAT international's corporate social responsibility policy for the Hatgyi dam project on the Salween river, Myanmar. (Master's thesis (International Development Studies)). Chulalongkorn University. Thailand.

Smith, N. (1984). Uneven development: Nature, capital and the production of space. Oxford: Basil Blackwell.

Spindler, W. (2015, December 1). Thousands of stateless people given nationality in Thailand. UNHCR. Retrieved from http://www. unhcr.org/afr/news/latest/2015/12/565db8939/thousands-stateless-people-given-nationality-thailand.html Spivak, G.C. (2010). Can the subaltern speak? Revised edition, from the history chapter of critique of postcolonial reason. In Rosalind C. Morris, (Ed.). Can the subaltern speak?: Reflections on the history of an idea. (pp. 21-78). New York: Columbia University Press. 
Tangseefa, D. (2003). Imperceptible naked-lives and atrocities: Forcibly displaced people and the Thai-Burmese in-between spaces. (Doctoral Dissertation). University of Hawaii at Manoa. United States. TERR. (2005). The Salween water diversion project. Retrieved from http:/ / www.terraper.org/web/sites / default/files / key-issues-content/1305711562_en.pdf

Thailand Burma Border Consortium. (2006). Internal displacement in eastern Burma. Survey. Bangkok: TBBC.

Thailand Burma Border Consortium. (2012). Burmese border displaced persons. Retrieved from http:/ / tbbc.org/camps/2012-01-jan-maptbbc-unhcr.pdf

The Border Consortium. (2012, January 31). The border consortium. Retrieved from https://reliefweb.int/report/myanmar/burmeseborder-displaced-persons-january-2012

The Border Consortium. (2017, April 4). The border consortium 2016 annual report. The Border Consortium. Retrieved from https:// reliefweb.int/sites/reliefweb.int/files/resources / 2016annual-report-jan-dec.pdf

Trakarnsuphakorn, P. (2008). Space of resistance and place of local knowledge in Karen ecological movement of northern Thailand: The case of Pgaz K'Nyau villages in Mae Lan Kham river basin. Southeast Asian Studies, 45(4), 586-614.

Tsing, A.L. (2005). Friction: An ethnography of global connection. Priceton, New Jersey: Princeton University Press.

Winichakul, T. (1994). Siam mapped: A history of the geo-body of a Nation. Chiang Mai: Silkworm Books.

Vandergeest, P., \& Peluso, N.L. (1995). Territorialization and state power in Thailand. Theory and Society, 24, 385-426.

Webster, A. (1998). British imperialism in Burma and Siam: 1820-1850. In Gentlemen capitalists: British imperialism in South East Asia, 1770-1890. (pp. 135-166). London: Tauris Academic Studies.

West, C., \& Zimmerman, D. (1987). Doing gender. Gender and Society, $1(2), 125-151$. 